\title{
FAKTOR YANG MEMPENGARUHI PASIEN POST OP FRAKTUR UNTUK MELAKUKAN RANGE OF MOTION (ROM)
}

\author{
Prita Devy Igiany \\ Prodi. Perekam dan Informasi Kesehatan, FKM, Universitas Veteran Bangun Nusantara \\ Email: pritadevyigiany90@gmail.com
}

\begin{abstract}
Range Of Motion (ROM) is an exercise performed to maintain or improve the ability to move the joints normally to increase muscle mass and tone. ROM is performed in patients with post-op fractures with the aim of reducing the risk of contractures and preventing thrombus formation in postop fracture patients. This study aims to determine the factors that influence post-op fracture patients to perform ROM in Cendrawasih Room II Arifin Achmad Hospital Pekanbaru. This study is a correlational study that is research that examines the relationship between variables, where the results of the study were analyzed using Fisher and Chi Square. Sampling in this study was purposive sampling with the number of respondents as many as 30 respondents from the population of post-op fracture patients. The results of this study indicate that there is no significant relationship between pain and knowledge of ROM implementation with a value of $p>0.05$. Based on the results of statistical tests for family support, there is a relationship between family support for the implementation of ROM with $\mathrm{p}<0.05$.
\end{abstract}

Keywords: post-op fracture, range of motion

\begin{abstract}
ABSTRAK
Range Of Motion (ROM) adalah latihan yang dilakukan untuk mempertahankan atau memperbaiki tingkat kemampuan menggerakkan persendian secara normal untuk meningkatkan massa dan tonus otot. ROM dilakukan pada pasien dengan post op fraktur dengan tujuan mengurangi resiko kontraktur dan mencegah pembentukan trombus pada pasien post op fraktur. Penelitian ini bertujuan mengetahui faktor yang mempengaruhi pasien post op fraktur untuk melakukan ROM di Ruang Cendrawasih II RSUD Arifin Achmad Pekanbaru. Penelitian ini merupakan penelitian korelasional yaitu penelitian yang mengkaji hubungan antar variabel, dimana hasil penelitian dianalisa menggunakan Fisher dan Chi Square. Pengambilan sampel pada penelitian ini adalah purposive sampling dengan jumlah responden sebanyak 30 responden dari populasi pasien post op fraktur. Hasil penelitian ini menunjukkan bahwa tidak terdapat hubungan yang signifikan antara nyeri dan pengetahuan terhadap pelaksanaan ROM dengan nilai $p>0.05$. Berdasarkan hasil uji statistik untuk dukungan keluarga yaitu terdapat hubungan antara dukungan keluarga terhadap pelaksanaan ROM dengan $p<0.05$.
\end{abstract}

Kata kunci: post op fraktur, ROM 


\section{PENDAHULUAN}

Fraktur adalah terputusnya kontinuitas jaringan tulang atau tulang rawan yang umumnya disebabkan oleh trauma kekuatan fisik (Mansjoer, 2000). Menurut World Health Organization (WHO) (2004) dalam penelitian Nasution (2010) cedera akibat kecelakaan lalu lintas tertinggi dijumpai dibeberapa negara Amerika Latin (41,7\%), Korea Selatan (21,9\%), Thailand (21\%). Kecelakaan lalu lintas merupakan penyebab fraktur (patah tulang) terbanyak (Departemen Perhubungan, 2010). Di Indonesia kecelakaan lalu lintas juga mengalami peningkatan dari tahun ketahun sehingga pada tahun 2000 sampai dengan tahun 2010 ditetapkan sebagai "Dekade Tulang dan Persendian" oleh WHO (Ariotejo, 2009).

Masalah yang sering muncul setelah pasien sadar dari operasi adalah edema, nyeri, keterbatasan lingkup gerak sendi (imobilisasi), penurunan kekuatan otot serta penurunan kemampuan untuk ambulasi dan berjalan karena luka bekas operasi dan luka bekas trauma (Smeltzer \& Bare, 2002). Gangguan mobilisasi fisik (imobilisasi) didefenisikan oleh North American Nurshing Diagnosis Association (NANDA) sebagai suatu keadaan ketika individu mengalami atau beresiko mengalami keterbatasan gerak fisik (Perry \& Potter, 2006).

Menurut Saryono (2008) keterbatasan mobilisasi akan menyebabkan otot kehilangan daya tahan tubuh, penurunan massa otot dan penurunan stabilitas. Pengaruh penurunan kondisi otot akibat penurunan aktivitas fisik akan terlihat jelas dalam beberapa hari. Massa tubuh yang membentuk sebagian otot mulai menurun akibat peningkatan pemecahan protein. Pada individu normal dengan kondisi tirah baring akan mengalami penurunan kekuatan otot rata-rata sekitar 3\% sehari. Atropi difuse sering terjadi akibat imobilisasi yang lama pada pemakaian gips, trauma, dan kerusakan saraf lokal. Istilah atrofi difuse digunakan untuk menggambarkan pengurangan ukuran normal serat otot secara patologis setelah inaktivitas yang lama akibat tirah baring, trauma, pemakaian gips, atau kerusakan saraf lokal (Perry \& Potter, 2006).

Bila individu tidak mampu melakukan latihan dan menggerakkan sendi melalui rentang gerak penuh, kontraktur dapat terjadi. Kontraktur adalah pemendekan otot dan tendon yang menimbulkan deformitas. Kontraktur dapat membatasi gerakan sendi. Bila sendi yang mengalami kontraktur digerakkan, pasien akan megalami nyeri (Smeltzer \& Bare, 2002).

Pasien yang mengalami perubahan fungsi fisiologis seperti nyeri selama latihan tidak akan tahan melakukan aktivitas. Alasan lain pasien tidak mampu melakukan aktivitasnya karena energi besar diperlukan untuk menyelesaikan aktivitas menyebabkan kelelahan dan kelemahan yang menyeluruh. Dukungan keluarga dan orang terdekat sangat penting perannya selama perawatan karena dapat meminimalkan efek gangguan psikososial (Saryono, 2008). Efek gangguan psikososial yang dimaksud adalah depresi, atau cemas sering tidak tahan melakukan aktivitas atau mobilisasi, karena mereka mengeluarkan energi yang cukup besar sehingga mudah lelah (Perry \& Potter, 2006). Menurut penelitian Yanti (2010) dukungan sosial dapat mempengaruhi pelaksanaan ambulasi dini pada pasien pasca operasi ekstremitas bawah. Sementara kurang pengetahuan tentang kegunaan pergerakan fisik merupakan salah satu faktor yang berhubungan dengan terjadinya kerusakan mobilitas fisik (Saryono, 2008).

Efek post op fraktur dapat dicegah dengan melakukan latihan Range Of Motion (ROM). ROM adalah latihan yang dilakukan untuk mempertahankan atau memperbaiki tingkat kesempurnaan kemampuan menggerakkan persendian secara normal dan lengkap untuk meningkatkan massa otot dan tonus otot. Tujuan dari Range Of Motion untuk mengurangi resiko kontraktur dan mencegah pembentukan trombus (Perry \& Potter, 2006). Menurut penelitian Rahmasari (2008) membuktikan bahwa ROM diperlukan untuk pemulihan kemampuan activities daily living (ADL) pasien post operasi fraktur femur. Selain itu penelitian yang dilakukan oleh Wiyono, Narko, Arifah, dan Siti (2008) dengan judul "Pengaruh ambulasi dini terhadap pemulihan peristaltik usus pada pasien paska operasi fraktur femur dengan anastesi umum di RSUI Kustati Surakarta". Metode yang digunakan adalah post test control only design. Taraf signifikansi 5\% atau $(p<0,05)$. Artinya terdapat pengaruh yang signifikan tindakan ambulasi mempercepat pemulihan peristaltik usus, yaitu ambulasi mempercepat pemulihan peristaltik usus pada pasien post operasi fraktur 
femur dengan anastesi umum. Dan kesimpulannya adalah ambulasi diperlukan bagi pasien post operasi dengan anastesi umum untuk mempercepat pemulihan peristaltik.

Menurut pengamatan peneliti pada saat studi pendahuluan, masih banyak ditemukan pasien tidak melakukan mobilisasi. Hal ini mungkin disebabkan karena nyeri insisi, kurangnya dukungan dari keluarga, dan ketidaktahuan pasien mengenai manfaat ROM. Masalah inilah yang mendorong peneliti melakukan penelitian mengenai faktor-faktor yang mempengaruhi pasien post op fraktur untuk melakukan ROM.

\section{METODE}

Penelitian ini merupakan penelitian korelasional. Populasi penelitian adalah pasien dengan diagnosa medis pasca bedah fraktur ekstremitas dengan jumlah sampel 30. Pengambilan sampel pada penelitian adalah dengan metode purposive sampling yaitu penetapan sampel dengan cara memilih sampel diantara populasi sesuai dengan kriteria inklusi yang ditetapkan peneliti. Adapun kiteria inklusi dalam penelitian ini antara lain pasien dalam keadaan sadar (compos mentis),didiagnosa fraktur, telah mendapat terapi bedah ortopedi, bisa membaca dan menulis, dan bersedia menjadi responden. Hubungan antar variabel dalam penelitian diuji dengan Chi Square dan Fisher.

\section{HASIL}

Tabel 1. Distribusi frekuensi karakteristik demografi 30 orang responden

\begin{tabular}{lcc}
\hline Karakteristik & Frekuensi Persentase & $\begin{array}{c}(\%) \\
\text { Umur } \\
<18\end{array}$ \\
\hline $18-35$ & 9 & 30 \\
\hline$>35-55$ & 19 & 63.3 \\
\hline Pendidikan & 2 & 6.7 \\
\hline SD & & \\
\hline SMP & 4 & 13.3 \\
\hline SMA & 13 & 43.3 \\
\hline PT & 11 & 36.7 \\
\hline Pekerjaan & 2 & 6.7 \\
\hline Tidak bekerja & & \\
\hline PNS/TNI/POLRI & 17 & 56.7 \\
\hline Wiraswasta & 0 & 0 \\
\hline
\end{tabular}

\begin{tabular}{lll}
\hline Petani & 0 & 0 \\
\hline Buruh & 2 & 6.7 \\
\hline
\end{tabular}

Berdasarkan tabel di atas diketahui bahwa dari 30 responden menunjukkan mayoritas umur responden adalah 18-35 sebanyak 19 responden $(63.3 \%)$ dan minoritas umur responden adalah >35-55 sebanyak 2 responden (6.7\%). Sedangkan mayoritas pendidikan responden adalah SMP sebanyak 13 reponden (43.3\%), dan minoritas Perguruan Tinggi sebanyak 2 responden (6.7\%). Untuk mayoritas pekerjaan responden adalah tidak bekerja sebanyak 17 responden $(5.7 \%)$, dan minoritas pekerjaan responden adalah buruh sebanyak 2 responden (6.7\%), sementara untuk pekerjaan PNS/TNI/POLRI tidak ada.

Tabel 2. Distribusi responden berdasarkan nyeri

\begin{tabular}{lll}
\hline Item nyeri & Frekuensi & $\begin{array}{l}\text { Persentase } \\
(\mathbf{\%})\end{array}$ \\
\hline Tidak mengganggu & 8 & 26.7 \\
Mengganggu & 22 & 73.3 \\
Jumlah & 30 & 100 \\
\hline
\end{tabular}

Tabel 2 menunjukkan nyeri responden tidak menganggu aktivitas dengan jumlah 8 responden (26.7\%), dan nyeri yang mengganggu sebanyak 22 responden $(73.3 \%)$.

Tabel 3. Distribusi responden berdasarkan pengetahuan

\begin{tabular}{lcc}
\hline Item pengetahuan & Frekuensi & $\begin{array}{c}\text { Persentase } \\
(\%)\end{array}$ \\
\hline Rendah & 15 & 50 \\
Tinggi & 15 & 50 \\
Jumlah & 30 & 100 \\
\hline
\end{tabular}

Berdasarkan tabel 3 persentase pengetahuan responden yang rendah dan tinggi sama, yaitu masing-masing 15 responden $(50 \%)$

Tabel 4. Distribusi responden berdasarkan dukungan keluarga

\begin{tabular}{|c|c|c|}
\hline $\begin{array}{l}\text { Dukungan } \\
\text { keluarga } \\
\end{array}$ & Frekuensi & $\begin{array}{c}\text { Persentase } \\
(\%)\end{array}$ \\
\hline Ada & 22 & 73.3 \\
\hline Tidak ada & 8 & 26.7 \\
\hline Jumlah & 30 & 100 \\
\hline $\begin{array}{l}\text { Berdasarkan tabel } \\
\text { dukungan keluarga } \\
(73.3 \%) \text { dan tidak } \\
\text { sebanyak } 8 \text { responde }\end{array}$ & $\begin{array}{l}4 \text { menun } \\
\text { sebanyak } \\
\text { adanya dul } \\
(26.7 \%) \text {. }\end{array}$ & $\begin{array}{lr}\text { kan } & \text { adanya } \\
2 & \text { reponden } \\
\text { gan } & \text { keluarga }\end{array}$ \\
\hline
\end{tabular}


Hasil analisa hubungan nyeri dengan pelaksanaan ROM pada pasien post op fraktur menunjukkan bahwa dari 30 orang responden terdapat 13 responden $(86.7 \%)$ yang tidak melakukan ROM terganggu oleh nyeri sedangkan, 2 responden $(13.3 \%)$ yang tidak melakukan ROM meskipun tidak terganggu oleh nyeri,. Data responden yang melakukan ROM 9 responden $(60 \%)$ yang melakukan ROM terganggu oleh nyeri sedangkan sebanyak 6 responden $(40 \%)$ tidak terganggu oleh nyeri. Hasil uji statistik menunjukkan $p$ sebesar 0.215 dimana $p>0.05$. Hal ini berarti bahwa $\mathrm{H} 0$ gagal ditolak dan dapat disimpulkan bahwa tidak ada hubungan antara nyeri dengan pelaksanaan ROM.

Hasil analisa hubungan pengetahuan dengan pelaksanaan ROM pada pasien post op fraktur menunjukkan bahwa dari 30 orang responden terdapat 10 responden $(66.7 \%)$ yang tidak melakukan ROM memiliki pengetahuan rendah, sedangkan 5 responden (33.3\%) yang tidak melakukan ROM memiliki pengetahuan tinggi. Data responden yang melakukan ROM sebanyak 5 responden $(33.3 \%)$ memiliki pengetahuan rendah, sedangkan 10 responden (66.7\%) yang melakukan ROM memiliki pengetahuan tinggi. Hasil uji statistik menunjukkan $p$ sebesar 0.068 dimana $p>0.05$. Hal ini berarti bahwa H0 gagal ditolak dan dapat disimpulkan bahwa tidak ada hubungan antara pengetahuan dengan pelaksanaan ROM.

Hasil analisa hubungan dukungan keluarga dengan pelaksanaan ROM pada pasien post op fraktur menunjukkan bahwa dari 30 orang responden terdapat 1 responden $(6.7 \%)$ yang tidak melakukan ROM tidak ada mendapatkan dukungan keluarga, sedangkan 14 responden $(93.3 \%)$ yang tidak melakukan ROM mendapatkan dukungan keluarga. Data responden yang melakukan ROM sebanyak 7 responden (46.7\%) tidak ada mendapatkan dukungan keluarga, sedangkan 8 responden (53.3\%) yang melakukan ROM mendapatkan dukungan keluarga.

Hasil uji statistik menunjukkan $p$ sebesar 0.035 dimana $p<0.05$. Hal ini berarti bahwa $\mathrm{H} 0$ ditolak dan dapat disimpulkan bahwa ada hubungan antara dukungan keluarga dengan pelaksanaan ROM.

\section{PEMBAHASAN}

1. Gambaran demografi karakteristik responden Berdasarkan dari hasil penelitian bahwa mayoritas umur pasien fraktur berada pada rentang usia 18-35 tahun (63,3\%). Fraktur lebih sering terjadi pada umur dibawah 45 tahun yang disebabkan oleh kecelakaan kendaraan bermotor (Reeves, Roux, \& Lockhart 2001). Mayoritas pekerjaan responden dari hasil penelitian yaitu tidak bekerja sebesar 56,7\%. Menurut Evans dalam penelitian Putra (2010) walaupun mayoritas responden yang mengalami fraktur tidak bekerja, namun hal tersebut tidak mempengaruhi terjadinya fraktur karena fraktur juga dapat menimpa pekerjaan apa saja. Berdasarkan pendidikan, mayoritas responden adalah lulusan SMP. Pendidikan yang diasosiasikan dengan pengetahuan ini juga mempengaruhi terjadinya fraktur. Pengetahuan terhadap nutrisi yang baik untuk membantu proses pertumbuhan tulang dan perbaikan sel. Kekurangan nutrisi bagi tubuh dapat menyebabkan kelemahan otot dan memudahkan terjadinya penyakit, seperti tubuh yang kekurangan kalsium akan lebih mudah mengalami fraktur (Hidayat, 2006).

2. Hubungan nyeri, pengetahuan, dukungan keluarga terhadap pelaksanaan ROM

Hubungan nyeri, pengetahuan, dukungan keluarga terhadap pelaksanaan ROM berdasarkan hasil penelitian didapatkan nilai signifikansinya dari uji fisher untuk nyeri $p=.215$ $(p>0.05)$. Dapat disimpulkan bahwa tidak terdapat hubungan yang signifikan antara nyeri terhadap pelaksanaan ROM. Hal ini bertolak belakang dengan pendapat Saryono (2008) dimana klien yang mengalami perubahan fungsi fisiologis seperti nyeri selama latihan tidak akan tahan melakukan aktivitas. Pada penelitian ini responden mendapat terapi analgetik untuk mengurangi nyeri sehingga nyeri yang dirasakan tidak berat. Menurut penelitian Yanti (2010) beberapa pasien menyatakan bahwa nyerinya lebih ringan dibandingkan sebelum pembedahan dan hanya memerlukan jumlah analgetik yang sedikit saja, harus diupayakan segala usaha untuk mengurangi nyeri dan ketidaknyamanan. Obat harus diberikan segera dalam interval yang ditentukan bila awitan nyeri dapat diramalkan misalnya $1 / 2$ jam sebelum aktivitas terencana 
seperti ROM. Pemberian analgetik inilah yang menyebabkan tingkat nyeri tidak mempengaruhi dilakukannya ROM.

Hasil penelitian didapatkan nilai signifikansi pengetahuan dari uji chi-square untuk pengetahuan yaitu $p=.068$. Karena nilai $p$ $>0.05$ maka dapat disiimpulkan bahwa tidak terdapat antara pengetahuan terhadap pelaksanaan ROM. Peneliti berasumsi walaupun pengetahuan responden baik dalam ROM, belum tentu responden mampu melakukan ROM. Hal ini sesuai dengan penelitian Yanti (2010) bahwa pengetahuan pasien yang baik tentang ambulasi tidak mampu melakukan latihan ambulasi tanpa dukungan dan bantuan keluarga/perawat. Hal ini karena dalam melakukan ROM keluarga terkadang tidak mampu membantu pasien sendiri sehingga membutuhkan bantuan dari perawat dalam memberikan ROM.

Berdasarkan hasil uji fisher untuk dukungan keluarga yaitu $p=.035$. Karena nilai $p<0.05$ hasil uji untuk dukungan keluarga yaitu terdapat hubungan antara dukungan keluarga terhadap pelaksanaan ROM. Orang yang depresi, cemas sering tidak tahan melakukan aktivitas. Dukungan keluarga dan orang terdekat selama perawatan dapat meminimalkan efek gangguan psikososial (Saryono, 2008). Dukungan keluarga merupakan faktor penting dalam pelaksanaan ROM karena pasien akan kesulitan melakukan ROM sendiri jika tidak dibantu oleh keluarga.

\section{SIMPULAN}

Hasil uji statistik fisher menunjukkan bahwa tidak terdapat hubungan yang signifikan antara nyeri terhadap pelaksanaan ROM dengan nilai nyeri yaitu .215. Hasil uji statistik untuk variabel pengetahuan didapatkan nilai signifikansi pengetahuan dari uji chi-square yaitu .068 , maka dapat disiimpulkan bahwa tidak terdapat hubungan antara pengetahuan terhadap pelaksanaan ROM. Berdasarkan hasil uji fisher untuk dukungan keluarga yaitu .035, maka dapat disimpulkan yaitu terdapat hubungan antara dukungan keluarga terhadap pelaksanaan ROM. Dari penelitian ini dapat disimpulkan bahwa pelaksanaan ROM akan sangat efektif jika dilakukan dengan adanya dukungan keluarga ataupun orang terdekat pasien.

\section{DAFTAR PUSTAKA}

Ariotejo, B. (2009). Cerebro Vaskuler Accident (CVA). Diperoleh tanggal 28 September $2010 \quad$ dari http://bimaariotejo.wordpress.com/2009/0 6/page/10/.

Departemen Perhubungan (2010). Epidemiologi kecelakaan lalu lintas. Diperoleh pada tanggal 23 Juni 2010 dari http://itd.idaho.gov/ohs/2009Data/Analysi s2009.pdf.

Evanjhie (2010). Phisychal Therapy. Diperoleh tanggal 1 Oktober 2010 dari http://evantherapy.

files.wordpress.com/2010/02/a21.jpg

Garrison, S. J. (2001). Dasar-Dasar Terapi \& Rehabilitasi Fisik (Widjaja Terj.). Jakarta: Hipokrates ( Naskah asli dipublikasikan tahun 1995).

Hanifah, A. (2010). Fraktur healing. Diperoleh tanggal 1 Oktober 2010 dari http://aasiyahhaniifah.blogspot.com/2010/ 07/fraktur-healing.html

Hidayat, A. A. A. (2006). Pengantar Kebutuhan Dasar Manusia Aplikasi Konsep dan Proses Keperawatan. Jakarta: Salemba Medika.

Hidayat, A. A. A. (2007). Riset Keperawatan \& Teknik Penulisan Ilmiah. Jakarta: Salemba Medika.

Hidayat, A. A. A. (2008). Metode Penelitian Keperawatan \& Teknik Analisis Data. Jakarta: Salemba Medika.

Mansjoer, A. (2000). Kapita Selekta Kedokteran Edisi 3. Jakarta: Media Aesculapius

Nasution, E. S. (2007). Karakteristik Penderita Cedera Kepala Akibat Kecelakaan Lalu Lintas Yang Rawat Inap Di Rumah Sakit Umum Padangsidimpuan. Diperoleh pada tanggal 3 Oktober 2010 dari 
Volume 01, No 02, Tahun 2018

ISSN: 2621-6612

Email: d3perinfokesunivet@gmail.com

Halaman: 18 -

http://repository.usu.ac.id/bitstream/1234 $\underline{\text { 56789/16495/5/Chapter\%20I.pdf }}$

Notoatmodjo, S. (2005). Metodologi Penelitian Kesehatan. Jakarta: Rineka Cipta.

Notoatmodjo, S. (2005). Promosi Kesehatan \& Ilmu Perilaku. Jakarta: Rineka Cipta.

Nursalam. (2008). Konsep Penerapan Metodologi Penelitian Ilmu Keperawan. Jakarta: Salemba Medika.

Perry, A. G. \& Potter, P A. (2006). Buku Ajar Fumdamental Keperawatan Konsep, Proses, dan Praktik Edisi 4. Jakarta: EGC.

Putra, R. A. D. (2010). Efektivitas Kompres Hangat Pada Area Lumbal Terhadap Penurunan Nyeri Pasca Bedah Fraktur Ekstremitas Bawah di RSUD Arifin Achmad Pekanbaru. Skripsi tidak dipublikasikan dari PSIK-UR.

Rahmasari, I. (2008). Pengaruh Range Of Motion (Rom) Secara Dini Terhadap Kemampuan Activities Daily Living (Adl) Pasien Post Operasi Fraktur Femur Di Rsui Kustati Surakarta. Diperoleh pada tanggal 12 Juli 2010 dari http://etd.eprints.ums.ac.id/890/.

Reeves, C. J. Roux, \& G. Lockhart, R. (2001). Keperawatan Medical Bedah Buku Satu(J. Setyono, Terj.). Jakarta : Salemba Medika. (Naskah asli dipublikasikan tahun 1999).

Saryono, (2008). Pemenuhan Kebutuhan Mobilitas Fisik Pada Pasien Di Ruang Bedah. Jakarta: Rekatama.

Smeltzer, S. C. \& Bare, B. G. (2002a). Buku Ajar Keperawatan Medikal Bedah Brunner \& Suddarth Edisi 8(A.Hartono \& H.Y. Kuncara, Terj.). Jakarta : EGC. (Naskah asli dipublikasikan tahun 1996).

Smeltzer, S. C. \& Bare, B. G. (2002b). Buku Ajar Keperawatan Medikal Bedah Brunner \& Suddarth Edisi 8(A.Hartono \& H.Y.
Kuncara, Terj.). Jakarta : EGC. (Naskah asli dipublikasikan tahun 1996).

Syahputra, A. (2010). Faktor-faktor yang mempengaruhi pasien pasca operasi stroke dalam melakukan Range of Motion (ROM). Skripsi tidak dipublikasikan dari PSIK-UR.

Tanjung, D. (2003). Asuhan Keperawatan Klien Dengan Ventilasi Mekanik. Diperoleh pada tanggal 30 Oktober 2010 dari http:// repository.usu.ac.id/bitstream/123456789/ 3600/1/keperawatandudut.pdf

Tseng, Chen, Wu, \& Lin (2000). Effects Of Range of Motion Exercise Programme. Diperoleh pada tanggal 31 september 2010 dari http://onlinelibrary.wiley.com/doi/10.111 1/j.13652648.2006.04078.x/abstract

Wasis, 2008. Pedoman Riset Praktis Untuk Profesi Perawat. Jakarta :EGC.

Wiyono, Narko, Arifah, \& Siti (2008). Pengaruh Ambulasi Dini Terhadap Pemulihan Peristaltik Usus Pasien Paska Operasi Fraktur Femur Dengan Anestesi Umum Di Rsui Kustati Surakarta. Diperoleh pada tanggal 12 juli 2010 dari http://eprints.ums.ac.id/1031/

Yanti, N. M. (2010). Analisis Faktor-Faktor Yang Mempengaruhi Pelaksanaan Ambulasi Dini Pada Pasien Pasca Operasi Fraktur Ekstrmitas Bawah Di Rindu B3 RSUP Adam Malik Medan. Diperoleh tanggal 17 Juli 2010 dari http://repository.usu.ac.id/bitstream/1234 56789/14302/ 1/10E01074.pdf 